\title{
Bank Profitability and its Determinants in Pakistan: A Panel Data Analysis after Financial Crisis
}

\author{
Muhammad Ali *
}

\begin{abstract}
This study seeks to investigate the internal and external determinants of the Pakistani banking sector, specifically after the recent financial crisis of 2008. The sample data comprises total 26 banks, which include 17 conventional, 5 Islamic and 4 public banks. The selected sample covers the period of five years from 2009 to 2013. A balanced panel data regression model has been used and considered return on assets (ROA) and return on equity (ROE) as an alternative of bank's profitability. The results of the study suggest that bank's profitability is significantly affected by its internal determinants while external determinants are insignificant. The study found that operating efficiency, liquidity, non-performing loans to total assets and real GDP have a negative impact, whereas financial risk, gearing ratio, asset management, bank size, deposits, loans to total assets and inflation show positive impact on the asset side. On the other side, operating efficiency, gearing ratio, asset management, liquidity, deposits and real GDP have a positive impact, while financial risk, bank size, asset quality and inflation exert negative impact on the equity side. During the study period, our findings suggest that the Pakistan banking industry has managed well to avoid significant impact of external factors like inflation and GDP over profitability, however, efficient management is required to improve internal factors to be more profitable.
\end{abstract}

Keywords: Banks, assets, operating costs, profits, assets size, bank-specific determinants, profitability.

\section{Introduction}

Banking institutions have a vital role to play in performing financial activities of an economy. They deal with financial instruments, payment mechanism, transfer and management of risk, assurance of transparency in financial markets and assessment of the behaviour of financial institutions. Particularly, Islamic banks have maintained their position well due to availability of potential target market (in Pakistan) (Ali \& Raza, 2015). It is also necessary for banks to create awareness about their products and services in order to become more profitable (Ali, Chin-Hong, \& Arif, 2015; Ali \& Raza, 2015; Ali, Chin-Hong, et al., 2015; Ali, Raza, \& Chin-Hong, 2015; Afshan \& Sharif, 2016). The banks are considered essential for economic functions as they also perform a critical role as financial intermediaries in the service providing economies. Furthermore, major crises can be caused by insolvencies by the bank. The profitability of banking sector not only contributes to the economic growth and stability of a financial system, but also enables the economies to endure the external and negative financial shocks (Athanasoglou, Brissimis, \& Delis, 2008). Therefore, it is crucial to understand profitability determinants.

\footnotetext{
*Department of Economics, Faculty of Economics and Business, Universiti Malaysia Sarawak, Kota

Samarahan, Sarawak 94300, Malaysia, E-mail: alisaleem_01@yahoo.com
} 
Banks not only contribute to economic growth but also provide people with opportunities to invest and save their money through secured and ensured mode of investment (Sufian \& Habibullah, 2009). For this reason, Anbar and Alper (2011) suggest that technological advancement allows banks to move from traditional banking systems to advance systems which, in turn, leads to increase in competition among the banks at national and international level.

Profitability has been the major concern of the banking system and there are various external and internal factors that can affect a bank's profitability. Past studies report external factors like liquidity, bank size, capitalization, operating efficiency, financial as well as external factors generally associated with macro-economic environment, such as inflation and GDP, to have a significant impact on profitability. However, one study of Shaikh, Sharif, and Arif (2015) argued that conventional banks are more volatile than Islamic banks in Pakistan.

Globally, the banking system is the direct victim of the recent financial crisis of 2008. Considering the Pakistani economy, the financial institutions, particularly banking industry received the significant impact of this crisis time. The liquidity crisis directly affected the confidence of the investors, but the overall banking industry did not collapse. At a glance, the banking sector's profitability has declined during H1-CY13 by 16.5 percent, mainly due to increase in cost of borrowings, charge of higher provisions against the classified portfolio and decline in the returns earned on the activities related to lending. Moreover, the earning indicators of ROE and ROA have also declined by 640 bps and 70 bps to 18.5 percent and 1.7 percent respectively. Furthermore, the shares of top 5 banks in terms of total profitability have increased to 74.2 percent in $\mathrm{H} 1 \mathrm{CY} 13$ as compared to 70.9 percent from last year as per the analysis of concentration in profitability. On the other hand, due to reduction in mark-up income on advances and loans, the banks' net interest income (NII) has been reduced by $18.4 \%$ during H1CY13. Nevertheless, the banking system has the resilience to bear the stress shock on liquidity, contagion, market and credit risk due to strong capital adequacy ratio. Essentially, all banks have capital adequacy ratios of above $13.1 \%$, which means that these banks can easily endure the solvency shock. However, liquidity stress shows that a sufficient fund provides the safety margin that is enough to meet significant volatile funds and withdrawals of deposits.

Previously, many studies have been conducted on banks' profitability (Levine \& Zervos, 1998; Bashir, 2003; Zopounidis \& Kosmidou, 2008; Naceur \& Omran, 2011).These studies were conducted with a panel of different countries and the actual determinants of a bank's profitability are inconclusive for an individual country like Pakistan. To the best of the author's knowledge, no such studies have been conducted on banks' profitability in Pakistan after the recent financial crisis of 2008 .

This study considered a panel of total 26 banks, which included 17 conventional, 5 Islamic and 4 public banks. This was the period when the banking system of Pakistan adopted more technological advancement. Furthermore, this study is different from previous studies in two main/important ways. Firstly, we investigated the bank's profitability in Pakistan on a panel of 26 banks covering the sample period mainly after the financial crisis. Secondly, previous studies considered Islamic and conventional banks separately and ignored public banks. But we have analyzed the overall banking sector of Pakistan, including private, Islamic and publicly owned banks.

The remaining parts of the study are based on the following sections. Chapter two of the study comprises past literature, chapter 3 represents data and methodology, chapter 4 provides results and estimations, and chapter five gives conclusion and policy implications. 


\section{Literature review}

Several empirical investigations have focused on identifying the factors that affect a bank's profitability in the recent times. Following are some of the studies that have targeted to explain the profitability of banks.

Miller and Noulas (1997) investigated large commercial banks' profitability in the late 1980s by using cross section and pooled time series cross section regression. The study sample covered the time period of 1985 to 1990 of total 201 banks. The results of the study suggest that banks' poor performance is due to real estate loans, while construction and land development loans have a significant and positive impact on commercial banks' profit. On the other side, these banks face negative impact of non-interest expense to total expense and loan loss provision to total loans. Overall findings recommend that interest income growth is less than non-interest income growth, while other loan categories register a sharp increase due to increase in consumer loans.

In addition, Demirgüç-Kunt and Huizinga (1999) highlighted the determinants of commercial banks' profitability by using the weighted least square method over the sample period of 1988 to 1995 of total 80 countries. The results of the study suggest that low cost funding leads to higher profitability, while inflation has positive impact on banks' profitability because banks manage their cost well under high inflation.

To better understand the performance of financial institutions, Azhar Rosly and Afandi Abu Bakar (2003) compared the performance of mainstream banks and Islamic banks in Malaysia. The profitability performance was measured through return on asset (ROA), asset utilization (AU), return on deposit (ROD), operating efficiency ratio (OER) and investment to interest margin. Results show that Islamic banks attain higher ROA as compared to mainstream banks, but this higher ROA does not show the efficiency of Islamic banks. In addition, the asset utilization and interest to investment margin in conventional banks were found to be significantly higher than Islamic banks. It can be concluded that the overall performance of conventional banks is higher than Islamic banks.

In the Middle East, Bashir (2003) investigation presented the internal and macro-economic factors' impact on the performance of Islamic banks. The findings of the study revealed that capital adequacy is positively associated with profitability, while inflation has a positive and significant impact on the profitability of Middle Eastern Islamic banks. Furthermore, foreign owned banks have a higher profitability ratio in contrast with locally owned banks.

A study conducted by Goddard, Molyneux, and Wilson (2004) on the profitability of European banks over the sample period of 1992 to 1998 by using the auxiliary regression model. Evidence presented in their study confirms that bank's profitability has insignificant association with the bank size, while the risk has a positive and significant impact on profitability.

Another study of Asutay and Izhar (2007) investigated the profitability of Islamic banks. Their study concluded that inflation has a negative and significant impact on Islamic bank's profitability while service activities of Indonesian Islamic banks do not impact their profitability. It can be concluded that Islamic banks of Indonesia should revise their policies for inflation so as to maximize their profitability.

In the same vein, profitability of Tunisia commercial banks was analyzed by Naceur and Goaied (2008) for the time period of 1980 to 2000. Their investigation found that bank size is negatively associated with banks' profit, whereas loans and stock market capitalization are positively associated with profitability. Overall findings suggest that Tunisian banks' profitability can be enhanced through privatization of state owned banks, national regulation program and development of the equity market.

Similarly, Sufian, Chong, et al. (2008) examined the profitability of Philippine banks by using 
a regression model over the sample period of 1990 to 2005. The author found that credit risk and bank size have a negative impact on profitability, while capitalization and non-interest income are positively associated with it. In addition, the inflation in the country influenced the banks' profitability negatively.

Sufian and Habibullah (2009) also draw our attention to Chinese commercial banks' profitability by using a regression model over the sample period of 2000 to 2005 . According to their findings, commercial bank's profitability is negatively associated with banks' overhead cost while credit risk, capitalization and liquidity risk have a positive impact on profitability. In view of their results, they recommend that Chinese banks should focus on cost effective products along with maximum utilization of their resources.

In 2010, Sufian and Habibullah conducted their study of Indonesian banks' performance during the financial crisis in the country over the sample period of 1990 to 2005 . Their findings demonstrated that bank size and financial crisis in the study sample period were negatively associated with Indonesian bank's profitability while it has a positive association with economic growth.

Ariss (2010) has analyzed the competitive conditions that exist in conventional and Islamic banking systems. Their investigation found the differences in profitability among these markets. The study have used a sample of 13 countries bank for the year 2000 to 2006 . The evidence reported in this study suggested that Islamic banks provide a greater share in the allocation of their assets to finance or loans as compared to conventional banks, which shows higher credit risk in Islamic banks. Overall, Islamic banks are not as significantly profitable as the conventional banks are, but Islamic banks' market is attracting more concentration compared to their peers.

Anbar and Alper (2011) investigated the specific and macroeconomic determinants of Turkish commercial banks for the sample period of 2002 to 2010 by applying multiple regression technique. Findings suggest that bank size and non-interest income have a positive impact on profitability, while bank loans are negatively associated with profitability. They recommend that through an increase in non-interest income and bank size, Turkish banks can enhance their profitability.

Saad and El-Moussawi (2012) investigation revealed that the inflation in Lebanon does not impact commercial banks' profitability, while credit risk has negative association with profitability over the sample period of 2000 to 2010. They further concluded that Lebanese commercial banks have an insignificant impact on profitability.

Tan and Floros (2012) identified the profitability of commercial banks in China over the sample period of 2003 to 2009 by using econometric techniques. Results presented by their investigation suggest that the bank size, non-traditional activity and taxation are negatively associated with banks' profitability, while Chinese banks are positively associated with high cost and high inflation rates.

A study of Masood, Masood, and Ashraf (2012) aimed to bank specific and macroeconomic determinants of Islamic banks. They considered a panel data of 25 Islamic banks from 12 countries over the sample period of 2006 to 2010 . The results of the study revealed that the bank size has a positive impact on Islamic banks' profitability, while asset management, capital adequacy and loans to assets are also a contributing factor to banks' ROA and ROE. In addition, RGDP has a negative impact on banks' ROA, while a positive impact on ROE. Operating efficiency, deposits and liquidity showed an insignificant impact on banks' profitability. It can be concluded that banks with efficient management and larger bank size can increase return on asset. 


\section{Data and Methodology}

In this study, panel data of total 26 banks, which included 17 conventional, 5 Islamic and 4 public banks, were used. The selected sample consisted of five years' data from 2009 to 2013, which mainly focused the recent financial crisis in Pakistan. For each bank, the data were collected on an annual frequency for bank specific variables gathered from the annual balance sheet and income statements. On the other side, the data for macro-economic variables of annual inflation and economic growth were obtained from World Bank database. The present study employs the Hausman test (whether the fixed effect is an appropriate or random effect appropriate) for study variables. This methodology is common for panel data and is in line with past empirical studies (Raza, Jawaid, \& Shafqat, 2013; Masood et al., 2012).

The list of selected variables along with their notation is presented in Table-1, while the explanation of profitability and its determinants is also given. (see appendix).

\section{Profitability Measure}

The profitability measures in previous studies are mainly used as ROA and ROE. Abbasoğlu, Aysan, and Gunes (2007); Zopounidis and Kosmidou (2008) used return on asset (ROA) as the dependent variable for profitability. ROA shows how banks generate their profit by using management's ability to utilize banks, real and financial investment Hassan and Bashir (2003). Furthermore, ROA is a good measure of profitability which is not significantly affected by high equity multipliers and firms can earn the maximum return on their asset portfolio Rivard and Thomas (1997). On the other side, return on equity (ROE) represents bank efficient management in utilizing its shareholders' investment. Hassan and Bashir (2003) suggest that most of the banks increase their ROE by getting more financially leveraged to competitive levels. Within the context of the above arguments, this study uses both ROA and ROE for profitability measures of the Pakistan banking system.

\section{Internal Determinants}

The internal determinants (independent variables) of profitability represent bank specific variables, which include Asset size (Log A), Asset quality (AQ), Liquidity (LQ), Asset management (OPI), Deposits (DEP), Gearing ratio (TDE), Operating efficiency (TOE) and Financial risk (TLA). Further explanation of internal determinants is detailed below;

\section{Asset size}

Asset size is used in this study as a proxy of bank size, which was mostly used in the previous studies as well. It is calculated by taking natural logarithm of total assets. Generally, bank size is positively associated with a firm's profitability (Smirlock, 1985).

\section{Asset quality}

The asset quality in this study is measured by two sub categories (1) non-performing loans to total assets (2) loans to total assets. Aydogan (1990) argued that asset quality can be measured through non-performing loans to total assets which reflects the bank's loan portfolio and is negatively associated with profitability. In addition, loans to total assets ratio is positively associated with profitability and it reflects the banks' income source. 


\section{Liquidity}

Liquidity of banks is measured through liquid assets to total assets which implies that banks are more liquid if the ratio is higher. Bourke (1989) found the impact of liquidity to be positive on profitability. Sometimes banks' failure is due to inadequate liquidity while the opportunity cost of higher return is expected, if more liquid assets are in hand.

\section{Asset Management}

Asset management is calculated by operating income divided by total assets. Chirwa (2003); Miller and Noulas (1997) found a positive relationship with profitability which indicate higher the asset management, higher will be the bank's profitability.

\section{Deposit}

Banks heavily depend on deposits and generally deposits are positively associated with banks' profitability. In addition, banks can transform their interest and profit earnings into loans to be more profitable.

\section{Gearing ratio}

This ratio is calculated through dividing debt by equity. In financial institutions, financial losses can be absorbed by the capital of the bank, which provides protection or assistance to the bank. When the debt to equity ratio is low, the most favorable condition is available for the bank.

\section{Operating efficiency}

The operating efficiency is measured by dividing total operating expenses with total assets. The bank's management efficiency is represented by operating efficiency, whereas better management efficiency is associated with lower operating ratio.

\section{Financial risk}

Financial risk is used as a proxy variable which is calculated by total liabilities to total assets ratio. It reflects higher leveraged or lower capital. This ratio generally has a negative impact on profitability.

\section{External Determinants}

External determinants (independent variables) of a bank's profitability are expected to impact bank's profitability. For this reason, two macro-economic variables are used: (1) Inflation (2) RGDP. These two variables have been frequently studied in the previous studies.

\section{Inflation}

In this study, annual inflation rate is used. Perry (1992) argued that bank's profitability depends on inflation in two cases. Anticipated and unanticipated inflation. The profitability is positively associated with inflation in anticipated case, while profitability is negatively linked with inflation in unanticipated inflation. 


\section{Real gross domestic product}

In this study, RGDP is used for total economic activity and inflation is adjusted. Deposits and loans are likely to be affected from GDP, whereas past empirical investigations found a positive association with GDP growth (Bikker, Hu, \& Bank, 2002; Demirgüç-Kunt \& Huizinga, 1999).

\section{Econometric Specification}

Bank profitability is measured through panel data which consist of $n$ cross-sections $n=1, \ldots$, $\mathrm{N}$ and is observed at time period $\mathrm{t}=1, \ldots, \mathrm{T}$. The total observations are $\mathrm{n} \times \mathrm{T}$ and the basic regression model of Brooks (2008) for this study is as follows

$$
Y_{n t}=\alpha+\beta X_{n t}+\epsilon_{n t}
$$

Where, $\mathrm{y}$ is denoted as the dependent variable (Profitability) and $\alpha$ denotes intercept term. $\mathrm{X}$ represents explanatory variables (Independent variables) while $\beta$ is regression coefficient. The basic functional form study model is as follows:

\section{Profitability $=f($ Bank Specific Variables; Macro-Economic Variables)}

Here, profitability of banks is measured through return on assets (ROA) and return on equity (ROE) while bank specific variables are Asset Size, Capital Adequacy, Assets Quality, Liquidity, Deposits, Income Expenditure Structure. Macro Economic Variables include Economic Activity and Inflation.

Based on the above discussion, the following 2 models have been used in this study:

$$
\begin{aligned}
R O A= & \alpha_{o}+\beta_{1} A S_{n, t}+\beta_{2} A Q L T_{n, t}+\beta_{3} A Q N P L_{n, t}+\beta_{4} L I Q_{n, t}+\beta_{5} D E P_{n, t}+\beta_{6} O P I_{n, t} \\
& +\beta_{7} T O E_{n, t}+\beta_{8} T D E_{n, t}+\beta_{9} T L A_{n, t}+\beta_{10} R G D P_{n, t}+\beta_{11} I N F_{n, t}+\epsilon_{n, t} \\
R O E= & \alpha_{o}+\beta_{1} A S_{n, t}+\beta_{2} A Q L T_{n, t}+\beta_{3} A Q N P L_{n, t}+\beta_{4} L I Q_{n, t}+\beta_{5} D E P_{n, t}+\beta_{6} O P I_{n, t} \\
& +\beta_{7} T O E_{n, t}+\beta_{8} T D E_{n, t}+\beta_{9} T L A_{n, t}+\beta_{10} R G D P_{n, t}+\beta_{11} I N F_{n, t}+\epsilon_{n, t}
\end{aligned}
$$

\section{Empirical estimations}

Table 2 represents the correlation matrix between explanatory variables used in multivariate regression analysis. This table reveals the degree of correlation. From the matrix, the correlation between the explanatory variables is not too high, suggesting the non-existence of multicollinearity in the model. When the correlation is 0.8 , (then there exists a multicollinearity problem which is not in our case.

To determine which method is appropriate between fixed effect and random effect model, Hausman test was used (Greene, 2000). In this test, if the null hypothesis (i.e. Country effects are not correlated with the regressors) is rejected, then fixed effect model is appropriate. Consequently, the results obtained from the Hausman test indicated that the null hypothesis is rejected and fixed effect model is appropriate for our study. The results estimated from the fixed effect model are presented in table 3 . 
Table 2

Correlations between Independent Variables

\begin{tabular}{lccccccccccc}
\hline & AQLT & AQNPL & DEP & LIQ & OPI & TOE & TLA & TDE & LNTA & INF & RGDP \\
\hline AQLT & 1.000 & & & & & & & & & & \\
AQNPL & -0.382 & 1.000 & & & & & & & & & \\
DEP & -0.618 & 0.571 & 1.000 & & & & & & & & \\
LIQ & -0.104 & -0.093 & 0.104 & 1.000 & & & & & & & \\
OPI & 0.511 & -0.616 & -0.078 & 0.011 & 1.000 & & & & & & \\
TOE & -0.540 & 0.631 & 0.065 & -0.061 & -0.055 & 1.000 & & & & & \\
TLA & 0.205 & -0.197 & -0.582 & 0.076 & 0.470 & -0.426 & 1.000 & & & & \\
TDE & 0.103 & 0.113 & -0.104 & -0.639 & 0.027 & 0.061 & 0.020 & 1.000 & & & \\
LNTA & -0.149 & 0.027 & 0.553 & 0.067 & -0.314 & 0.112 & -0.069 & 0.018 & 1.000 & & \\
INF & 0.003 & 0.016 & -0.022 & 0.143 & 0.057 & 0.052 & 0.062 & -0.056 & -0.136 & 1.000 & \\
RGDP & -0.041 & -0.044 & 0.033 & -0.242 & -0.034 & -0.057 & -0.073 & 0.041 & 0.142 & -0.508 & 1.000 \\
\hline Source: Authors' Estimation & & & & & & & & & &
\end{tabular}

To determine which method is appropriate between fixed effect and random effect model, Hausman test was used (Greene, 2000). In this test, if the null hypothesis (i.e. Country effects are not correlated with the regressors) is rejected, then fixed effect model is appropriate. Consequently, the results obtained from the Hausman test indicated that the null hypothesis is rejected and fixed effect model is appropriate for our study. The results estimated from the fixed effect model are presented in table 3 .

Table 3 shows that the operating efficiency (TOE) of banks is negatively associated with return on assets (ROA). This result supports the findings from the previous studies of (Sufian \& Habibullah, 2009; Alexiou \& Sofoklis, 2009) which observed negative impact on return on assets (ROA). The financial risk (TLA) has a positive and significant impact on return on assets (ROA) which means that banks use their deposits as leverage type and depositors are the part of risk sharing. These findings are consistent with (Masood et al., 2012). The gearing ratio (TDE) shows positive and significant impact on return on assets (ROA) which signifies that the profitability of banks increases with higher level of gearing ratio. The positive and significant relationship was found between asset management (OPI) and return on assets (ROA). These findings are consistent with past studies of (Miller \& Noulas, 1997; Chirwa, 2003). The study finds that bank size (Log A) has a positive and significant impact on return on assets (ROA) and supports previous study findings of (Smirlock, 1985; Masood et al., 2012). Furthermore, Liquidity (LQ) has a negative and significant association with return on assets (ROA) which is consistent with (Molyneux \& Thornton, 1992; Guru, Staunton, \& Balashanmugam, 2002). As expected, the deposit ratio shows positive and significant impact on return on assets (ROA) which signifies that banks can increase their profitability by increasing their deposit ratio. The asset quality ratio of banks is divided into two ratios.

1. Loans to total asset (AQLT)

2. Non-performing loans to total assets (AQNPL)

In our findings, AQNPL ratio shows a negative and insignificant impact on return on equity (ROA) which imply that increase in non-performing loans lead to decrease in profitability whereas AQLT ratio impact positive and significant on return on equity (ROA). For macro-economic determinants, a real gross domestic product (RGDP) has a negative and insignificant impact on return on assets (ROA). This result supports previous studies of Masood et al. (2012) whereas inflation have a positive and insignificant effect on return on assets (ROA) supporting (Guru et al., 2002; Jiang, Tang, Law, \& Sze, 2003; Pasiouras \& Kosmidou, 2007; Sufian, 2009; García-Herrero, Gavilá, \& Santabárbara, 2009; Tan \& Floros, 2012) findings. 
In addition, the value of adjusted $\mathrm{R}^{2}$ is 0.7428 which implies that all explanatory variables jointly predict $74.28 \%$ return on assets. The probability value of F-statistics shows that the overall model is significant and best fit for the analysis.

Table 3

Determinants of Return on Assets (ROA)

\begin{tabular}{lrrl}
\hline \multirow{2}{*}{ Variables } & \multicolumn{3}{c}{ FEM } \\
\cline { 2 - 4 } & Coeff. & t-stats & Prob \\
\hline C & 0.0294 & 0.3088 & 0.7584 \\
TOE & -0.2464 & -0.7842 & 0.4355 \\
TLA & 0.0156 & 2.2192 & $0.0297^{* *}$ \\
TDE & 0.0882 & 4.0417 & $0.0001^{*}$ \\
OPI & 0.0041 & 2.3133 & $0.0236^{* *}$ \\
Log A & 0.0140 & 2.5927 & $0.0116^{* *}$ \\
LIQ & -0.0044 & -1.7035 & $0.0928^{* * *}$ \\
DEP & 0.0672 & 2.4266 & $0.0178^{* *}$ \\
AQNPL & -0.0439 & -0.2817 & 0.7789 \\
AQLT & 0.1955 & 2.8509 & $0.0057^{*}$ \\
RGDP & -0.0003 & -0.5513 & 0.5831 \\
INF & 0.0012 & 0.7346 & 0.4650 \\
\hline Adj. $R^{2}$ & \multicolumn{3}{c}{0.7428} \\
F-stats (Prob.) & \multicolumn{3}{c}{$9230(0.000)$} \\
\hline Source: Authors' Estimation \\
Note: *1, **5 and ***10\% level of significance
\end{tabular}

Table 4 represents the bank specific and macro-economic determinants of return on equity (ROE). The operating efficiency (TOE) has a positive and significant impact on return on equity (ROE) which supports Wasiuzzaman and Nair Gunasegavan (2013) findings. The financial risk has a negative and significant effect on return on equity (ROE) which indicates that banks with lower capital or higher leverage can impact negatively on profitability. The gearing ratio (TDE) and asset management (OPI) of banks are positively and significantly associated with return on equity (ROE).

Table 4

Determinants of Return on Equity (ROE)

\begin{tabular}{lrrl}
\hline \multirow{2}{*}{ Variables } & \multicolumn{3}{c}{ FEM } \\
\cline { 2 - 4 } & Coeff. & t-stats & Prob \\
\hline C & 7.9695 & 4.7337 & 0.0000 \\
TOE & 0.2970 & 2.4796 & $0.0170^{* *}$ \\
TLA & -1.0133 & -6.2193 & $0.0000^{*}$ \\
TDE & 13.8803 & 6.7352 & $0.0000^{*}$ \\
OPI & 4.7890 & 2.2297 & $0.0308^{* *}$ \\
Log A & -1.2045 & -6.681 & $0.0000^{*}$ \\
LIQ & 0.0310 & 2.1671 & $0.0356^{* *}$ \\
DEP & 0.0381 & 1.3786 & 0.1748 \\
AQNPL & -0.2300 & -2.5877 & $0.0130^{* *}$ \\
AQLT & -0.0591 & -1.6657 & 0.1027 \\
RGDP & 0.0246 & 0.5490 & 0.5857 \\
INF & -0.0019 & -0.6910 & 0.4931 \\
\hline Adj. $R^{2}$ & \multicolumn{3}{c}{0.8353} \\
F-stats (Prob.) & \multicolumn{3}{c}{$14.2274(0.000)$} \\
\hline Source: Authors' Estimation \\
Note: *1, **5 and ***10\% level of significance
\end{tabular}


The results are consistent with Masood et al. (2012) findings. Wasiuzzaman and Nair Gunasegavan (2013) also found that bank size has negative impact on profitability which further supports our findings. Moreover, liquidity (LQ) has a positive and significant impact on return on equity (ROE), supporting Wasiuzzaman and Nair Gunasegavan (2013) investigations while deposits (DEP) have a positive association but an insignificant impact on return on equity (ROE). In addition, AQNPL and AQLT ratios are negatively associated with return on assets (ROE), but they have a significant and an insignificant impact respectively. Findings from Masood et al. (2012) support our results for non-performing loans. On the other hand, real gross domestic product (RGDP) impacts positively, but insignificantly, while inflation has a negative and an insignificant impact on return on equity (ROE), which is supported by Masood et al. (2012); Wasiuzzaman and Nair Gunasegavan (2013) findings. The value of adjusted $R^{2}$ is 0.8353 which imply that all explanatory variables jointly predict $83.53 \%$ return on equity. The probability value of F-statistics show that the overall model is best fit for analysis.

\section{Conclusion and Policy implications}

The present study is the first attempt in Pakistan to investigate the profitability of the banking sector after the recent financial crisis. Our investigation determined bank specific and macroeconomic variables by using the panel data of 26 banks, which included 17 conventional banks, 5 Islamic banks and 4 public banks over the sample period of 2009 to 2013 . This study used panel data method (fixed effect model) whereas return on assets (ROA) and return on equity (ROE) was used as profitability measures.

Based on empirical findings, operating efficiency found a negative and insignificant impact on the asset side, while positive and significant effect on the equity side. Financial risk has a positive association with return on assets (ROA) whereas negative relationship with return on equity (ROE). Similarly, bank size has a positive impact on profitability. For the sample under study, the gearing ratio and asset management show positive and significant impact on banks' profitability. We have further found that gearing ratio and asset management exert positive and significant impact on profitability. Bank size, on the other hand, has a positive and significant effect on the asset side, while a negative and significant impact on the equity side, but liquidity has a negative and significant impact on return on assets (ROA), while positive and significant on return on equity (ROE). The asset quality for non-performing loans to total deposits has negative impact on profitability, but asset quality loans to total assets contribute positively on the asset side and negatively on the equity side.

The impact of economic growth is insignificant on profitability, but it is negatively associated with the asset side while positively associated with the equity side. Conversely, inflation has a positive impact on return on asset (ROA) and a negative impact on return on equity (ROE), but the impact is insignificant on profitability.

The empirical results obtained from this study have reasonable policy relevance. It could be argued that more new products and services can help banks to be more profitable. For this reason, technology advancement is a major tool for banks to have a competitive advantage over their peers. The success of the Pakistan banking sector depends on profitability, efficiency and competitiveness. Consequently, profitability allows banks' management and policy makers to find alternative solutions to use their resources for optimal level of output. Additionally, return on investment is an important element and has the ability to minimize risk to ensure the competitiveness of the Pakistani banking industry. Therefore, the regulatory and policy implication is directed towards increasing the profitability of the banking sector. 


\section{References}

Abbasoğlu, O. F., Aysan, A. F., \& Gunes, A. (2007). Concentration, competition, efficiency and profitability of the Turkish banking sector in the post-crises period. Retrieved from http://mpra.ub.uni-muenchen.de/5494/1/MPRA_paper_5494.pdf

Afshan, S., \& Sharif, A. (2016). Acceptance of mobile banking framework in Pakistan. Telematics and Informatics, 33(2), 370-387.

Alexiou, C., \& Sofoklis, V. (2009). Determinants of bank profitability: Evidence from the Greek banking sector. Economic Annals, 54(182), 93-118.

Ali, M., Chin-Hong, P., \& Arif, I. (2015). Determinants of e-banking adoption: A nonusers perspective in Pakistan. Retrieved from https://mpra.ub.uni-muenchen.de/ 67878/1/MPRA_paper_67878.pdf

Ali, M., Chin-Hong, P., et al. (2015). Factors affecting intention to use Islamic personal financing in Pakistan: Evidence from the modified TRA model. Retrieved from https://mpra.ub.uni-muenchen.de/66023/1/MPRA_paper_66022.pdf

Ali, M., \& Raza, S. A. (2015). Service quality perception and customer satisfaction in Islamic banks of Pakistan: the modified SERVQUAL model. Total Quality Management \& Business Excellence, 1-19. doi: 10.1080/14783363.2015.1100517

Ali, M., Raza, S. A., \& Chin-Hong, P. (2015). Islamic home financing in Pakistan: A SEM based approach using modified TPB model. Retrieved from https://mpra.ub.uni -muenchen.de/67877/1/MPRA_paper_67877.pdf

Anbar, A., \& Alper, D. (2011). Bank specific and macroeconomic determinants of commercial bank profitability: Empirical evidence from Turkey. Business and Economics Research Journal, 2(2), 139-152.

Ariss, R. T. (2010). Competitive conditions in Islamic and conventional banking: A global perspective. Review of Financial Economics, 19(3), 101-108.

Asutay, M., \& Izhar, H. (2007). Estimating the profitability of islamic banking: evidence from bank muamalat indonesia. Review of Islamic Economics, 11(2), 17-29.

Athanasoglou, P. P., Brissimis, S. N., \& Delis, M. D. (2008). Bank-specific, industryspecific and macroeconomic determinants of bank profitability. Journal of International Financial Markets, Institutions and Money, 18(2), 121-136.

Aydogan, K. (1990). An investigation of performance and operational efficiency in Turkish banking industry (Tech. Rep.). Retrieved from http:// www . tcmb.gov.tr/wps/wcm/connect/12a81dd2-69df-415d-ac79-e203145be966/ 9022eng . pdf ?MOD=AJPERES\&CACHEID=12a81dd2-69df-415d-ac79-e203145be 966

Azhar Rosly, S., \& Afandi Abu Bakar, M. (2003). Performance of Islamic and mainstream banks in Malaysia. International Journal of Social Economics, 30(12), 1249-1265.

Bashir, A.-H. M. (2003). Determinants of profitability in Islamic banks: Some evidence from the Middle East. Islamic Economic Studies, 11(1), 31-57.

Bikker, J. A., Hu, H., \& Bank, N. (2002). Cyclical patterns in profits, provisioning and lending of banks. De Nederlandsche Bank.

Bourke, P. (1989). Concentration and other determinants of bank profitability in Europe, North America and Australia. Journal of Banking ES Finance, 13(1), 65-79. 
Chirwa, E. W. (2003). Determinants of commercial banks' profitability in Malawi: A cointegration approach. Applied Financial Economics, 13(8), 565-571.

Demirgüç-Kunt, A., \& Huizinga, H. (1999). Determinants of commercial bank interest margins and profitability: Some international evidence. The World Bank Economic Review, 13(2), 379-408.

García-Herrero, A., Gavilá, S., \& Santabárbara, D. (2009). What explains the low profitability of Chinese banks? Journal of Banking \& Finance, 33(11), 2080-2092.

Goddard, J., Molyneux, P., \& Wilson, J. O. (2004). The profitability of european banks: A cross-sectional and dynamic panel analysis. The Manchester School, 72(3), 363-381.

Greene, W. H. (2000). Econometric Analysis. Pearson Education India.

Guru, B. K., Staunton, J., \& Balashanmugam, B. (2002). Determinants of commercial bank profitability in Malaysia. Journal of Money, Credit, \& Banking, 17, 69-82.

Hassan, M. K., \& Bashir, A.-H. M. (2003). Determinants of Islamic banking profitability. In 10th erf annual conference, morocco (pp. 16-18).

Jiang, G., Tang, N., Law, E., \& Sze, A. (2003). Determinants of bank profitability in Hong Kong. Hong Kong Monetary Authority Quarterly Bulletin, 2003, 5-14.

Levine, R., \& Zervos, S. (1998). Stock markets, banks, and economic growth. American Economic Review, 537-558.

Masood, O., Masood, O., \& Ashraf, M. (2012). Bank-specific and macroeconomic profitability determinants of Islamic banks: The case of different countries. Qualitative Research in Financial Markets, 4 (2/3), 255-268.

Miller, S. M., \& Noulas, A. G. (1997). Portfolio mix and large-bank profitability in the USA. Applied Economics, 29(4), 505-512.

Molyneux, P., \& Thornton, J. (1992). Determinants of European bank profitability: A note. Journal of Banking \& Finance, 16(6), 1173-1178.

Naceur, S. B., \& Goaied, M. (2008). The determinants of commercial bank interest margin and profitability: evidence from Tunisia. Frontiers in Finance and Economics, 5(1), 106-130.

Naceur, S. B., \& Omran, M. (2011). The effects of bank regulations, competition, and financial reforms on banks' performance. Emerging Markets Review, 12(1), 1-20.

Pasiouras, F., \& Kosmidou, K. (2007). Factors influencing the profitability of domestic and foreign commercial banks in the European Union. Research in International Business and Finance, 21 (2), 222-237.

Perry, P. (1992). Do Banks Gain or Lose From Inflation. Journal of Retail Banking, 14, $25-30$.

Raza, S. A., Jawaid, S. T., \& Shafqat, J. (2013). Profitability of the Banking Sector of Pakistan: Panel Evidence from Bank-Specific, Industry-Specific and Macroeconomic Determinants. Retrieved from http://mpra.ub.uni-muenchen.de/48485/1/MPRA _paper_48485.pdf

Rivard, R. J., \& Thomas, C. R. (1997). The effect of interstate banking on large bank holding company profitability and risk. Journal of Economics and Business, 49(1), $61-76$.

Saad, W., \& El-Moussawi, C. (2012). The Determinants of Net Interest Margins of Commercial Banks in Lebanon. Journal of Money, Investment and Banking, 23, 
$117-132$.

Shaikh, A., Sharif, S., \& Arif, I. (2015). Comparison of islamic banks with conventional banks: Evidence from an emerging market. Retrieved from http://www.researchgate.net/profile/Imtiaz_Arif2/publication/ 272506616_Comparison_of_Islamic_banks_with_Conventional_banks_Evidence _from_an_emerging_market/links/54e780f30cf277664ffad71b.pdf

Smirlock, M. (1985). Evidence on the (non) relationship between concentration and profitability in banking. Journal of Money, Credit and Banking, 69-83.

Sufian, F. (2009). Determinants of bank profitability in a developing economy: Empirical evidence from the China banking sector. Journal of Asia-Pacific Business, 10(4), 281-307.

Sufian, F., Chong, R. R., et al. (2008). Determinants of bank profitability in a developing economy: empirical evidence from the Philippines. Asian Academy of Management Journal of Accounting and Finance, 4(2), 91-112.

Sufian, F., \& Habibullah, M. S. (2009). Bank specific and macroeconomic determinants of bank profitability: Empirical evidence from the China banking sector. Frontiers of Economics in China, 4(2), 274-291.

Tan, Y., \& Floros, C. (2012). Bank profitability and inflation: The case of China. Journal of Economic Studies, 39(6), 675-696.

Wasiuzzaman, S., \& Nair Gunasegavan, U. (2013). Comparative study of the performance of Islamic and conventional banks: The case of Malaysia. Humanomics, 29(1), 4360 .

Zopounidis, C., \& Kosmidou, K. (2008). The determinants of banks' profits in Greece during the period of EU financial integration. Managerial Finance, 34(3), 146-159. 
Table 1

Profitability determinant of Bank

\begin{tabular}{lllc}
\hline \multirow{2}{*}{ Determinants } & Variable & Measure & Notation \\
\hline \multirow{2}{*}{ Dependent variable } & \multirow{2}{*}{ Portability } & Return on assets (ROA) $=$ net profit/total assets & ROA \\
& Return on equity (ROE) $=$ net profit/equity & ROE \\
\hline & Asset size & Natural logarithm of total assets & LogA \\
& Asset quality & Loans/total assets & AQLT \\
& Liquidity & Non-performing loans/total assets & AQNPL \\
\multirow{2}{*}{ Bank-specific } & Leposits & Deposits/total assets & LQ \\
& Asset Mgt & Operating income/total assets & DP \\
& Operating efficiency & Total operating expense/total assets & OPI \\
& Gearing ratio & Total debt/total equity & TOE \\
& Financial risk & Total liabilities/total assets & TDE \\
& Economic activity & Annual real GDP growth rate & TLA \\
\hline \multirow{2}{*}{ Macro-economic } & Inflation & Annual inflation rate & RGDP \\
& & & IF \\
\hline
\end{tabular}

Table 5

List of Sample Banks of the Study

\begin{tabular}{clll}
\hline Sr.No & Conventional banks & Islamic banks & Public banks \\
\hline 1 & Allied Bank Ltd & Al Barakah bank Ltd & Bank of Punjab Ltd \\
2 & Askari Bank Ltd & Bank Islami Pakistan Ltd & Bank of Khyber Ltd \\
3 & Bank Alfalah Ltd & Burj Bank Ltd & National Bank of Pakistan Ltd \\
4 & Bank Al habib Ltd & Dubai islamic Bank Ltd & First women Bank Ltd \\
5 & Faysal Bank Ltd & Meezan Bank Ltd & \\
6 & Habib Bank Ltd & & \\
7 & Habib Metro bank Ltd & & \\
8 & JS Bank Ltd & & \\
9 & KASB Ltd & & \\
10 & MCB Ltd & \\
11 & Samba Bank Ltd & & \\
12 & Silk Bank Ltd & & \\
13 & Soneri Bank Ltd & & \\
14 & Standard chartered bank Ltd & & \\
16 & Summit Bank Ltd & & \\
17 & Bnited Bank Ltd & & \\
\hline
\end{tabular}

